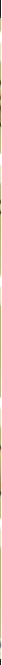

Editor:

Jaime Almansa Sánchez

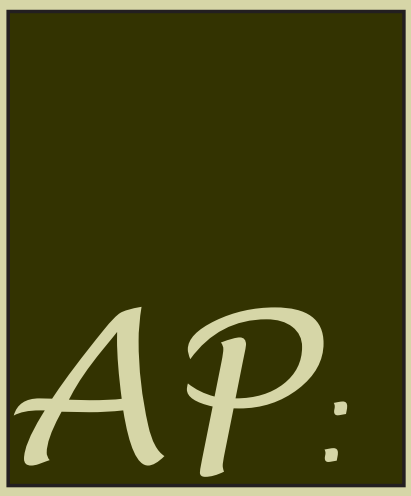

www.arqueologiapublica.es

Ontine Journat in Public Archaeology 


\title{
REVIEWS
}

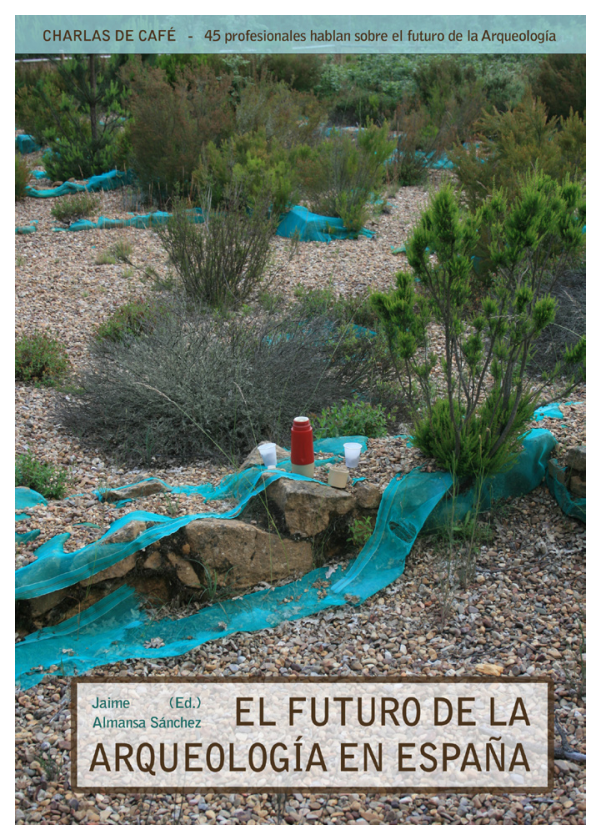

José María SEÑORÁN MARTÍN

INCIPIT-CSIC

\section{El futuro de la arqueología en España}

[Ed. by Jaime Almansa Sánchez]

\begin{abstract}
JAS Arqueología Editorial ISBN: 978-84-938146-8-7 298 pages
\end{abstract}

It is complicated to write a report on a book that is not yet finished; this is precisely the situation in which we currently find ourselves. The work reviewed in this article is part of a wider project, also unfinished, and the result of Jaime Almansa's (the author) idea, whose ultimate objective is to progress towards a Public Archaeology or to be precise, towards the socialisation of Archaeology. It is important to stress these objectives, rather than focus exclusively on the book, whose suggestive title is a clear declaration of intent. The fact that the book is unfinished, is reflected in the blog to which it is linked: http://elfuturodelaarqueologia.blogspot.com/, which is open to online publication of new chapters. In fact, the book currently includes three extra chapters in its online version. We also need to emphasize the commitment of the publishing company to Spanish Archaeology; for example, $1 €$ of each book sold goes to AMTTA (Asociación Madrileña de Trabajadores y Trabajadoras en Arqueología). This organization is currently advocating the development of a working agreement in the Archaeology sector in Madrid. 
Once we have mentioned some peripheral aspects of the book, we must focus on the work itself. We must highlight that, since a few years ago, the direction that the archaeological sector is taking disconcerts many within this sphere. I would like to apologise for starting this article with negative comments, but somehow this feeling comes from the book that it is reviewed here. These negative feeling is shared by the majority of those who have participated in the book. However, despite this, they suggest solutions for the current situation of Archaeology, with the aim to benefit the leading professionals as well as society, this being the main beneficiary of our Archaeological Heritage.

The book that is reviewed in this article is the result of an idea which the author has been working on for many years; his aim is to present the current situation of the sector from different perspectives and make proposals for the improvement of this professional body in all its areas. To achieve this, the author has selected a wide variety of participants, 44 (plus himself) to be exact, who offer their particular vision of Archaeology and of its current situation. It is worth noting that the participants come from different geographical and professional areas.

The participating authors come from a variety of professional areas, such as PhD students, researchers from a wide range of research centres, such as CSIC (Spanish National Research Council), physical anthropologists, sociologists, etc. However, the majority of the work has been carried out by archaeologists, particularly those linked to Commercial Archaeology.

In relation to the geographical diversity of the authors, we need to highlight two aspects; first, most of Spain's Autonomous Communities are represented in the book by one or several authors. However, some regions, such as Ceuta, Melilla and Aragón, are not represented at all. It would have been interesting to illustrate the concerns and ideas of professionals from these areas of the country. With reference to the geographical location, we must also highlight that some authors deal with the topic at a general level, paying particular attention to issues such as circulation of information, research, etc., whilst others present the current situation of the particular region where they work; this is true in the case of Valentín Álvarez in Asturias or David Javaloyas in Islas Baleares.

With regards to the issues addressed in the book, one topic concerns the current situation of Commercial Archaeology; there are 
actually 28 chapters that deal directly with this issue (Ch. 1, 3, 5, $7,8,9,10,13,14,15,16,18,19,20,23,25,26,27,28,29,30$, $31,34,39,40,41,42,43)$. This is also a reflection of the number of participants involved directly or indirectly with Commercial Archaeology. The crisis in the area of Commercial Archaeology has been discussed in recent years in several scientific articles (such as in Parga-Dans and Varela 2011, Moya Maleno 2010). This book illustrates how Spanish Commercial Archaeology has been hindered partly due to the "crisis del ladrillo" (a metaphor that could be translated as a recession in the construction industry), although we should include this crisis within a wider phenomenon; Felipe Criado links it with a general recession (economical, social, political and cultural). Commercial Archaeology developed in Spain without any control or restraints, in parallel with the development of large infrastructures within the building industry. The failure of this economic model, based upon the building industry, has hindered the development of Commercial Archaeology. Although most authors blame the recession of Commercial Archaeology on this failure, authors such as Eva Parga and David Barreiro state that the reasons for this recession are deeper and involve structural problems in the sector.

Further reasons for this crisis may relate to the weakness of the Spanish market within which Commercial Archaeology is set, driven by "the need of combining the protection of Cultural heritage with economic profits" (Moya Maleno, 2010, 9). However, we need to explain, as David Barreiro states, that the causes are deeper and more complex and the solution to the current problems will arise only by developing an economic model that guarantees appropriate and reasonable working conditions and by the socialization of Cultural Heritage, separate from the speculative market in which Spanish economy is embedded. In this sense, we need to highlight the contribution of Eva Zarco and Alba Masclans. Zarco addresses the associativism in Madrid, AMTTA in particular, which is key to the development of a collective working agreement in this region of Spain. Masclans explains how the professional archaeological sector has made use of existing organizations, such as CNT (National Confederation of Labour), to improve working conditions. These are illustrated as an "unreal account" in works by Carlos Marín and Riccardo Frigoli. Other authors also consider that innovations in the professional field are necessary. The objective is to not restrict Archaeology to excavations in sites that are set up for infrastructure and construction development. 
Another important aspect of the book is to create an active relationship between universities and archaeological companies. In recent years, the number of excavations in Spain has risen astronomically, as the data compiled by Gonzalo Aranda demonstrate. The problem is that a large part of the excavation reports will be filed away and forgotten about by administrators without being analyzed accurately. There may be different solutions to this, from creating mixed projects between universities and archaeological companies to including funds for research in archaeological projects' budgets. At this point, we can also mention the problems related to the administrative procedures in Archaeology. Instigated by Ley 16/1985 de Patrimonio Histórico Español (the Spanish Cultural Heritage Law) and the handover of responsibilities to the Autonomous Communities, each of which has opted for a different administrative model. We must bring to attention the work of Gonzalo Aranda and Margarita Sánchez Romero, who show how the administrative model created in Andalucia can be used as an exemplary model as it is based on Preventative Archaeology.

Other important aspects are those in relation to academic formation in Archaeology (Ch. 1, 3, 6, 11, 13, 15, 16, 17, 18, 19, 20, 24, 25, $26,27,35,40,41)$. Universities have not planned the curricula in accordance with the needs of the sector, particularly of the commercial sector, as stated by Valentín Álvarez. This is one of the weaknesses of archaeological studies in Spain. Spanish universities, as opposed to other European universities (British universities, for example), do not provide the appropriate curriculum plans. The numerous changes in the educational system implemented in Spain throughout the last 25 years have not secured the right model. After the implementation of the Bolonia Plan, Universidad Autónoma de Barcelona, Universidad de Barcelona and Universidad Complutense de Madrid have created a Archaeology degrees. This means that Archaeology is now recognised as a scientific discipline in itself. However, the fact that this has been implemented only in three universities in the country demonstrates the magnitude of the problem. Maybe we should consider whether creating Archaeology degrees in all Spanish universities is necessary; it may be more appropriate to create specialised departments where excellence is the driving force.

Other important topics relate to the dissemination of information, which is dealt with in 29 chapters (Ch. 2, 4, 6, 7, 8, 9, 11, 12, 16, $19,21,23,25,28,30,31,32,33,34,35,36,37,38,39,40,41$, $42,43,44)$; this illustrates the interest in this issue. It seems clear 
that the direction that archaeological research should take is towards socialising Heritage. Hence the importance of didactics, as stated by M. Carmen Rojo. In this sense, as stated by Agustín Azkárate, new models of political engagement, oriented to the democratization of the development of technology and science, should be created. It is also worth mentioning Jorge Rolland's contribution, who advocates in favour of pedagogy and reflects on how we produce knowledge, rejecting the differentiation between non-experts and experts, bringing Heritage closer to the general public and avoiding an elitist Archaeology, as stated by Arturo Ruiz.

Finally, it is worth mentioning the issue of research; this is dealt with in 17 chapters of the book (Ch. 2, 3, 4, 6, 7, 10, 15, 17, 19, 23, $24,32,33,35,38,41,42)$. Traditionally, research has been linked to public centres (museums, universities, research centres). In the reviewed book, the author evidences how in recent years, due to the lack of collaboration between research centres and companies, a large percentage of archaeological excavations have only resulted in administrative reports. It is necessary to link up Academia and Commercial Archaeology as proposed by Roberto Ontañón, who rejects the current impermeability, resistance and lack of recognition. Moreover, Agustín Azkárate advocates in favour of multidisciplinary projects.

In conclusion, we must stress that the book offers a quite complete understanding of the current situation of Archaeology in Spain, offering diverse solutions to a variety of different problems. We must understand that, considering the general crisis affecting our country, Spanish Archaeology, in order to have a future, needs to take Europe into account, as stated by Pilar López. In order to achieve this, Spanish Archaeology needs to focus on certain basic principles, such as Heritage socialisation, empowerment of communities, multidisciplinary projects and good administration.

\section{References}

Parga-Dans, E. and Varela-Pousa, R. 2011. Caracterización socioeconómica de la Arqueología Comercial española. Resultados de la primera encuesta nacional dirigida a empresas del sector, Complutum 22(1), 9-25.

Moya Maleno, P. R. 2010. Grandezas y miserias de la arqueología de empresa en la España del siglo XXI, Complutum, 21(1), 9-26. 


\section{AP: Ontine Journat in Public Archaeology}

\section{Editor:}

Jaime Almansa Sánchez

Email: almansasanchez@gmail.com

Assistant editor:

Elena Papagiannopoulou

Edited by:

JAS Arqueología S.L.U.

Website: www.jasarqueologia.es

Email: jasarqueologia@gmail.com

Address: Plaza de Arteijo 8, T-2, 28029 - Madrid (Spain)

$--$

Cover Image: Storyboard for a PSA in Philly (H. Winograd and M. Haas)

Copyright ( 2012 JAS Arqueología S.L.U. (edition) \& Authors (content)

ISSN: $2171-6315$

Quotation:

Señorán, J.M. 2012. Review: El futuro de la arqueología en España.

AP Journal Vol. 2, 157-161.

AP Journal is a peer-reviewed journal devoted exclusively to Public Archaeology. It is freely distributed online on the Website:

www.arqueologiapublica.es

You can also follow us on:

Blogger:

=- http://arqueologiapublica.blogspot.com/

Twitter:

http://twitter.com/APjournal

Facebook:

i http://www.facebook.com/APJournal 